\title{
TINJAUAN TEOLOGIS TERHADAP POSTMODERNISME DAN IMPLIKASINYA BAGI IMAN KRISTEN
}

\author{
Made Nopen Supriadi \\ Sekolah Tinggi Teologi Arastamar Bengkulu \\ madenopensupriadi@sttab.ac.id
}

\begin{abstract}
Times have changed, from pre-modern to modern, and now into postmodern times. The postmodern era is also followed by philosophical thinking from postmodernism. These philosophical thoughts have greatly influenced the lives of many people, who have also touched on aspects of the Christian faith. The principles of postmodernism are subjectivism, anti-history, perspective pluralism, and relativity. These principles have a negative influence on the principles of the Christian faith so that postmodernism is one of the challenges in the Christian faith. The challenge is that postmodernism is an objective anti-truth philosophy. So that it affects the lives of believers so that they remain faithful to reveal the final truth of the Christian faith, making Christian faith the only test tool against postmodernism and dismantling the falsity of postmodernism. Therefore this article was written to provide an understanding of postmodernism and its implications for the Christian faith so that many believers can provide anticipation in the postmodern era that is lived today.

Keywords: Overview, Theological, Postmodernism and Implications.
\end{abstract}

Abstraksi: Zaman mengalami perubahan, dari pra modern menuju ke modern dan sekarang memasuki era postmodern. Era postmodern juga diikuti oleh pemikiran filosofis dari postmodernisme. Pemikiran filosofis tersebut telah jauh memperngaruhi kehidupan banyak manusia, yang juga telah menyentuh dalam aspek iman kristen. Prinsip pemikiran postmodernisme yaitu subyektifisme, anti sejarah, pluralisme perspektif dan relativitas. Prinsip-prinsip tersebut menimbulkan pengaruh negatif bagi prinsip-prinsip iman Kristen sehingga postmodernisme adalah salah satu tantangan dalam iman Kristen. Tantangan tersebut adalah postmodernisme adalah filsafat anti-kebenaran yang objektif. Sehingga berpengaruh kepada kehidupan orang percaya agar tetap setia untuk menyatakan kebenaran final iman Kristen, menjadikan iman Kristen sebagai satu-satunya alat uji terhadap postmodernisme dan membongkar kepalsuan postmodernisme. Oleh karena itu artikel ini ditulis untuk memberikan pemahaman mengenai postmodernisme dan implikasinya bagi iman Kristen, sehingga banyak orang percaya dapat memberikan antisipasi di zaman postmodern yang dihidupi pada saat ini.

Kata Kunci: Tinjauan, Teologis, Postmodernisme dan Implikasi.

\section{PENDAHULUAN}

Realita menunjukkan pemikiran zaman modern telah diruntuhkan oleh postmodernisme sehingga pemikiran zaman ini berisikan pemikiran zaman 
pramodern. ${ }^{1}$ Hadirnya pemikiran postmodern tidak terhindarkan oleh banyak umat manusia, termasuk orang percaya. Postmodernisme merupakan filosofi dari zaman postmodern, paham ini telah banyak mempengaruhi sistem berpikir dalam kehidupan manusia. Pengaruh yang diberikan oleh postmodernisme juga mendapat respon dari banyak ahli. Heryanto menuliskan ada dua respon dari pakar sosiologi di Indonesia terhadap postmodernisme, yaitu: sikap hyper korektif (puritan) dan represif. ${ }^{2}$ Selain para pakar sosiologi, para teolog Kristen juga memberikan respon terhadap postmodernisme. ${ }^{3}$

Perbedaan sikap para teolog dalam merespon postmodernisme menunjukkan bahwa tidak mudah untuk memberikan tanggapan terhadap postmodernisme, kesulitan tersebut jika tidak diselesaikan akan berdampak menimbulkan kebingungan dalam kehidupan keKristenan. Dengan demikian sangat penting memahami apa postmodern itu sesungguhnya?. Prinsip apa yang sedang ditawarkan? Tantangan apa yang diberikan bagi iman Kristen?. Bagaimana tinjauan teologi terhadap tantangan dari postmodernisme Apa pengaruhnya bagi iman Kristen?. Oleh karena itu tulisan ini akan menyajikan tinjauan teologis untuk menyelesaikan pertanyaan tersebut.

1 Wetzel van Huyssteen: Postmodernisme bukanlah sekedar fase budaya baru setelah modern, bukan pula periode baru dalam sejarah, serta bukan pula suatu kesatuan keyakinan yang baru, bukan filsafat baru, bukan teori atau doktrin baru, melainkan lebih dari pada sikap, yaitu cara pandang yang berbeda dan sesungguhnya bertentangan dengan cara pandang modern secara total dan radikal (Lih. Wetzel van Huyssteen, Theology and Justification of Faith: Constructing Theories in Systematic Theology (Grand Rapids: William B Eerdmans Publishing Company, 1989), 40.)

2 Heryanto menuliskan ada dua postmo-phobia, yaitu: pertama, hiper korektif dan puritan. Rekasi ini datang dari cendekiawan senior yang ingin membuktikan diri bahwa mereka lebih tahu, kalau bukan paling tahu, sejarah intelektual perancis khususnya. Khususnya tentang tokoh-tokoh awal postmodernisme. Mereka menuduh kaum muda yang kini membahas postmodernisme di Indonesia sebenarnya salah satu atau kurang mengerti postmodernisme yang "sejati". Kedua, sikap represif, dengan berbagai olok-olok dan umpatan kasar, ada yang menghendaki perbincangan tentang postmodernisme segera dihentikan. Alasannya beraneka, Indonesia dianggap perlu modern dulu, atau postmodernisme dianggap sampah beracun. (Lih. Ariel Heryanto, "Postmo-Phobia," Jawa Pos, 17 April 1994.)

3 Bayu Probo, "Teologi Postmodern Ditolak Atau Diterima?," Satu Harapan, 25 September 2014, http://www.satuharapan.com/read-detail/read/teologi-postmodern-ditolak-atau-diterima. 


\section{METODE PENULISAN}

Metode penulisan yang digunakan adalah metode deskriptif. ${ }^{4}$ Metode ini akan mendeskripsikan pemahaman terhadap postmodernisme, baik itu definisi istilah, sejarah, prinsip postmodernisme, tantangan terhadap iman Kristen, tinjauan teologis dan implikasi. Data-data penelitian dikumpulkan dengan cara melakukan riset dan studi terhadap literatur-literatur yang mendukung pendeskripsian topik terkait. Penyelesaian masalah dalam penelitian ini juga menggunakan pendekatan Teologis, penulis secara khusus akan memberikan jawaban dengan prinsip Teologi Reformed.

\section{HASIL}

Hasil dari penelitian ini adalah untuk memberikan penjelasan secara ringkas apa dan bagaimana postmodernisme itu. Selanjutnya memberikan penjelasan mengenai perkembangan zaman dari zaman pra-modern, modern dan postmodern. Selanjutnya hasil penelitian ini untuk menjelaskan bagaimana prinsip-prinsip pemikiran postmodenisme yang akan ditinjau secara teologis.

Hasil penelitian ini juga untuk menunjukkan bahwa Teologi Kristen secara khusus Teologi Reformed memiliki prinsip kebenaran yang berbeda dengan pemikiran postmodernisme serta memberikan pandangan bagaimana harusnya sikap orang percaya dalam merespon tantangan yang ditimbulkan oleh postmodernisme. Hasil akhir dari penelitian ini adalah memberikan implikasi terhadap postmodernisme dari pemikiran Teologi Reformed. Dalam bentuk jawaban keberatan terhadap postmodernisme.

4 Tjutju Soendari, "Metode Penelitian Deskriptif," file.upi.edu, UPI, diakses 15 Agustus 2020, http: //file.upi.edu /Direktori/FIP/JUR. _PEND._LUAR_BIASA/ 195602141980032TJUTJU_ SOENDARI/ Power_Point_Perkuliahan/Metode_PPKKh/Penelitian__Deskriptif.ppt_[Compatibility_Mode].pdf. 


\section{PEMBAHASAN}

Postmodernisme terdiri dari tiga kata yaitu post, modern dan isme. Kata post yang berarti later or after, ${ }^{5}$ kata modern yang memiliki arti up to date, ${ }^{6}$ dan kata isme merupakan akhiran (sufiks) yang artinya tindakan atau praktik, keadaan atau kondisi, prinsip, doktrin, teori dan sistem atau aliran. ${ }^{7}$ Maka secara etimologi postmodernisme adalah praktik, keadaan atau kondisi, prinsip, teori, sistem atau aliran dan karakteristik dari masa yang melewati atau melampaui masa modern. Kevin O Donnel menuliskan istilah postmodern dapat diterjemahkan dengan "sesudah sekarang."8 Selanjutnya Ramly menuliskan postmodernisme adalah 'pemikiran baru' tentang kehidupan di balik zaman postmodern. ${ }^{9}$ Dengan demikian dapat ditarik kesimpulan postmodernisme adalah suatu paham atau pokok pemikiran yang menjadi paradigma baru sebagai antithesis dari modernisme.

\section{Sejarah Zaman Menuju Postmodernisme}

Dalam pembahasan sejarah zaman, hanya memfokuskan perkembangan pemikiran secara khusus dalam konteks pemikiran keKristenan pada era pra modern, modern dan postmodern.

\footnotetext{
5 Kata post merupakan sebuah preposisi, yang memiliki 2 arti, yaitu: pertama, berkaitan dengan tempat, dimana kata post berarti di belakang. Kedua, berkaitan dengan waktu dan urutan, kata post berarti kemudian, sesudah atau berikutnya. (Lih. K. Prent, Kamus Latin-Indonesia (Yogyakarta: Kanisius, 1969), 658.)

${ }^{6}$ Kata modern berasal dari bahasa latin modernus yang berarti sekarang. (Lih. C.L. Barnhart \& Jess Stein, The American College Dictionary (New York: Random House and Toronto, 1964), 781). Bdg. Willy Gaut menuliskan dengan demikian, modern sangat kontras dengan yang kuno, tua atau hal yang lama.(Lih. Willy Gaut, Filsafat Postmodernisme: Jean Francois Lyotard (Maumere: Penerbit Ledalero, 2010).)

${ }^{7}$ Anton M. Moeliono, Kamus Besar Bahasa Indonesia (Jakarta: Balai Pustaka, 1990), 589.

8 Kevin O'Donnell, Postmodernisme (Yogyakarta: Kanisius, 2009), 6.

9 Ramly B. Lumintang, Bahaya Postmodernism Dan Peranan Kredo Reformed (Batu: PPII, 2010), 38.
} 


\section{Era Pramodern (Abad I - XVI) ${ }^{10}$}

Pada era ini kehidupan manusia, baik dalam tingkat pengetahuan dan sosial masih sederhana. ${ }^{11}$ Selanjutnya pada era pramodern adalah masa awal yang dimulai dari middle age (reinassance). Dalam konteks keKristenan era ini dikuasai oleh agama. ${ }^{12}$ Sistem keagamaan saat itu bersifat "form follow meaning". ${ }^{13}$ Sehubungan dengan hal tersebut Hali Daniel Lie menuliskan:

Kebenaran agamawi mendapatkan tempat utama di dalam hati manusia. Segala cabang ilmu lainnya mesti menyelaraskan diri kepada teologia. Apabila terjadi pertentangan di antara keduanya maka kebenaran agamawilah yang dijadikan patokan. Melalui satu kalimat pendek: agama mendominasi sains. ${ }^{14}$

Dengan demikian kebenaran agamawi mendapatkan tempat utama di dalam hati manusia. Maka pada zaman pramodern agama memiliki wilayah yang dominan dalam mengatur kehidupan manusia.

\section{Era Modern (Abad XVII-XX) ${ }^{15}$}

10 N N, "Middle Ages," en.wikipedia.org, Wikipedia, diakses 10 Agustus 2019, http://en.wikipedia.org/wiki/Middle_Ages.

11 Douglas Groothuis, Pudarnya Kebenaran Membela,...,18 bdg. Abdy Bustan yang menuliskan: "pada zaman ini (pra modern), tingkat pengetahuan dan peradaban manusia terbagi dalam beberapa level, mulai dari era pemburu dan peramu, hortikultur sederhana, hortikultur sederhan kontemporer, hortikultur intesif, masyarakat agraris, hingga masyarakat pastoralis." (Lih. Abdy Bustan, "Postmodernisme," www.kompasiana.com, Kompasiana, 24 Juni 2014, https://www.kompasiana. com/abdibusthan/5975d1c02bbb132bfd12c022/postmodernisme?page=all.)

12 Era kekuasaan Kristen di dalam budaya Barat dipandang sebagai contoh utama dari eksistensi pramodern. Masyarakat umumnya disatukan di bawah satu agama, yang merumuskan berbagai aturan, peran, dan keyakinan. Orang-orang yang tidak percaya dan para pemeluk agama lain - seperti Yahudi dan Muslim - merupakan kaum terpinggir dan seiring dianiaya. Agama, negara, dan budaya amat terkait satu sama lain, atau bahkan tercampur secara institusional. Teisme dipandang sebagai hal yang lumrah. Ketika Thomas Aquinas menulis karya besarnya summa contra Gentiles (Treatise Againts the Unbelievers), ia mungkin tak pernah bertemu dengan seorang yang tidak percaya. Hal ini tidak berati bahwa kekuasaan Kristen saat itu bersifat Alkitabiah secara sempurna atau bahwa terdapat kesepakatan penuh dalam doktrin, etika dan praktik. Mitologi kafir dan okultisme, seperti juga pemikiran filosofis non-Kristen, hadir. Akan tetapi, periode pramodern abad pertengahan dicirikan oleh otoritas budaya yang cukup stabil. (Lih. Douglas Groothuis, Pudarnya Kebenaran (Surabaya: Momentum, 2010), 18-19.)

${ }^{13}$ Form follow meaning artinya sistem keagaamaan yang terikat oleh konsep-konsep pertandaan yang bermuara pada spiritualitas. (Lih. Bustan, "Postmodernisme.")

14 Hali Daniel Lie, "Abad Pertengahan, Modernisme \& Postmodernisme," Jurnal Teologi Stulos 8 (2009): 1, https://www.academia.edu/ 38587556/Abad_Pertengahan_Modernisme_and_Postmodernisme.

15 N N, "Modernisme," en.wikipedia.org, Wikipedia, diakses 10 Agustus 2019, https: /len.wikipedia.org /wiki/Modernisme. 
Era modern ditandai dengan bertumbuhnya pemikiran renaissance dan englightement untuk menggali kembali kekayaan sastra klasik. Humanisme yang berkembang serta teknologi yang ditemukan membawa manusia pada peradaban modern. Pada era enlightement manusia mengalami pencerahan dalam pola pikir. Sehingga membentuk situasi di mana manusia menggunakan rasionalitasnya untuk menjawab masalah-masalah dalam kehidupannya. Perkembangan ini juga berpengaruh dalam konsep beriman, manusia mulai terus menggali bukti-bukti rasional tentang iman. ${ }^{16}$

Pada era modern telah terjadi pergeseran prinsip terhadap cara pandang teologia dan sains, filsafat tidak lagi menjadi ancilla theologiae tetapi menjadi the master of philosophy. Douglas Groothuis menyatakan era modern ditandai dengan konsep-konsep pemikiran yang rasionalitas, objetivitas yang universal, perkembangan sains dan kemajuan historis. ${ }^{17}$ Dengan demkian era modern membawa manusia pada pemikiran rasional yang banyak melahirkan pengetahuan dan teknologi yang berguna bagi kehidupan manusia.

\section{Era Postmodern (Abad XX-Sekarang)}

Era postmodern tidak memiliki waktu yang jelas kapan dimulainya, namun beberapa catatan menujukkan pada masa Nietzh pemahaman tentang postmodernitas telah muncul. Pemikiran Nietzsche tentang manusia super menunjukkan mulai tumbuhnya postmodernisme. ${ }^{18}$ D.A. Lyon menuliskan : since

\footnotetext{
16 Lie, "Abad Pertengahan, Modernisme \& Postmodernisme."

17 Groothuis, Pudarnya Kebenaran, 20-21.

18 Lihat karya Nietzsch "Setelah sepuluh tahun bertapa di gunung-gunung, Zarathustra (40 tahun) memutuskan kembali ke dalam kehidupan masyarakat. la sampai disebuah sebuah desa yang mengelilingi hutan. Ketika memasuki desa itu, sang pertapa memperhatikan bahwa banyak orang sudah berkumpul di pasar. Kepada orang banyak itu, Zarathustra mengumandangkan matinya Allah dan munculnya manusia super (Ubermensch) (Lih. Allan Megill, Prophets of Extremity: Nietzsche, Heidegger, Foucault, Derrida (Berkeley and Los Angeles: University of California Press, 1985), 2.)
} 
the 1980s the social sciences have engaged with a growing debate over 'postmodernity', a debate having close affinity with paralel (postmodern/ist) discussions within the arts, including particulary architechture. ${ }^{19}$. Dengan demikian era postmodern dimulai ketika ilmu sosial mendiskusikan tentang sains. $^{20}$

Dari pemahaman di atas dapat disimpulkan bahwa postmodernisme merupakan sintesa atau perpaduan pemikiran pra modern dan modern. Namun pandangan berbeda menyatakan kesadaran manusia untuk merenungkan kembali sepak terjang modernisme dengan segala kehebatan di dalamnya yang justru merusak banyak kehidupan manusia. Hasil perenungan dan introspeksi itu melahirkan postmodernisme. ${ }^{21}$ Prinsip berpikir postmodernisme mensitesiskan dunia modern dengan pemikiran pra modern. ${ }^{22}$ Pemikiran pra modern digali kembali untuk menjawab kekurangan yang ada pada modernisme. Namun perpaduan tersebut membentuk sebuah pemikiran baru yang justru mempertanyakan prinsip modernisme tentang keabsolutan. Sehingga pemikiran postmodernisme menghasilkan pemikiran yang relatif.

\section{Prinsip Pemikiran Postmodernisme}

Ada banyak tokoh yang membentuk pemikiran tentang postmodernisme. I Bambang Sugiharto menuliskan arah pemikiran postmodernisme menjadi dua.

19 D.A. Lyon Kon, "Modernity And Postmodernity," dalam New Dictionary of Christian Ethics \& Pastoral Theology, ed. oleh David J. Atkinson dkk. (Illionis: IVP Academic, 1995), 597.

${ }^{20}$ Akhyar Yusuf Lubis, Postmodernisme: Teori dan Metode (Jakarta: Rajawali Press, 2014), 29.

21 Lie, "Abad Pertengahan, Modernisme \& Postmodernisme."

22 Perubahan era dari modern kepada era postmodern, bukanlah hanya perubahan waktu dan peradaban dunia di semua sektor kehidupan, seperti sosial, politik, ekonomi dunia, melainkan yang mendasar adalah perubahan yang lebih radikal, yaitu perubahan cara pandang (worldview). Semua cara pandang dan standar kebenaran modern yang obyektif, rasional dan universal ditolak dan diganti oleh dengan tanpa standar, yang subyektif, yang irrasional dan yang lokal. Filsafat ini mencoba melakukan revisi atas klaim-klaim prinsip kebenaran masa modern, sehingga pemikiran yang dihasilkan pada masa postmodern ini yaitu kebenaran bersifat relatif (Lih. : Stevri I. Lumintang, Introduksi Theologia Sistematika (Jakarta: IThl, 2019), 11.) 
Pertama, menunjuk kepada kritik-kritik filosofis atas gambaran dunia (wold view), epistemologi dan ideologi-ideologi modern. Kedua, menunjuk pada situasi dan tata sosial produk teknologi informasi, globalisasi, fragmentasi gaya hidup, konsumerisme yang berlebihan, deregulasi pasar uang dan sarana publik. $^{23}$ Berdasarkan sifatnya tokoh-tokoh postmodernisme dibagi menjadi dua kelompok, yaitu kelompok dekonstruktif dan kelompok konstruktif. ${ }^{24}$

Selanjutnya Johan Setiawan menuliskan lima tokoh yang berpengaruh dalam pemikiran postmodernisme terhadap ilmu pengetahuan, yaitu: JeanFrancois Lyotard, Michael Foucault, Jacques Derrida, Jean Baudrillard dan Fedrick Jameson. ${ }^{25}$ Merekalah yang memberikan pengaruh dalam banyak apek pemikiran postmodernisme.

Pada bagian ini akan membahas pemikiran postmodernisme, secara khusus dalam pemikrian ini hanya menuliskan prinsip-prinsip umum yang juga memberikan pengaruh secara khusus dalam berbagai bidang kehidupan manusia di zaman postmodern, yaitu subyektif, anti-sejarah, pluralisme perspektif dan relativisme.

\section{Subyektifisme}

Subyektifisme adalah sebuah pemikiran yang mendasarkan subyek sebagai kebenaran. Dalam konteks postmodernisme subyek tersebut menunjuk kepada

24.

${ }^{23}$ I. Bambang Sugiharto, Postmodernisme : Tantangan Bagi Filsafat (Yogyakarta: Kanisius, 1996), 24 Sugiharto, 16.

25 Johan menuliskan: Jean-Francois Lyotard: sesuatu ilmu tidak harus langsung diterima kebenarannya harus diselidiki dan dibuktikan terlebih dahulu. Michael Foucault: pengetahuan bersifat subyektif. Jacques Derrida: filsafat dekonstruksi (mengurai, meleapskan dan membuka). Jean Baudrillard: dunia postmodernisme sebagai kehidupan yang hiperealitas. Fedrick Jameson: menggunakan pola berpikir Marxis untuk menjelaskan epos historis. (Lih.: Johan Setiawan dan Ajat Sudrajat, "Pemikiran Postmodernisme Dan Pandangannya Terhadap IImu Pengetahuan," Jurnal Filsafat 28, no. 1 (28 Februari 2018): 25, https://doi.org/10.22146/jf.33296.) 
manusia sebagai interpretor. Hal senada juga dinyatakan oleh Sugiharto, ia menjelaskan postmodernisme menunjuk kepada kritik-kritik filosofis atas gambaran dunia (world view), epistemologi dan ideologi-ideologi modern. ${ }^{26}$ Mengenai prinsip subyektifisme Stevri I. Lumintang menuliskan:

Semua bisa benar, karena kebenaran adalah perspektif, yaitu tergantung dari sudut pandang mana saja, termasuk tergantung dari sudut pandang iman agama manapun. Selain berdasarkan perspektif, kaum postmo juga menekankan bahwa kebenaran itu adalah temporal, bisa berubah sesuai konteks. Akhirnya, mereka menegaskan bahwa kebenaran itu adalah kombinasi semua kebenaran yang ada. ${ }^{27}$

Dengan demikian kehidupan postmodernisme adalah gambaran kehidupan dimana manusia beralih dari pemikiran modern yang objektif kepada pemikiran yang bersifat subyektif. Dengan demikian hal-hal yang diputuskan secara obyektif dapat ditolak secara subyektif jika pribadi tersebut tidak setuju.

\section{Posmo-Anti Sejarah}

Prinsip dari postmodernisme adalah menolak keobyektifan hasil dari sejarah. Data obyektif sejarah telah ditolak oleh pemikiran postmodernisme yang bersifat subyektifisme. Mengenai pandangan postmodernisme yang anti sejarah Ariel Heryanto menuliskan pemahamannya: "dalam berbagai ragamnya, posmo memusuhi sejarah, karena sejarah merupakan narasi yang cenderung bersifat total, universal, rasional dan linear." 28 Selanjutnya lebih dalam David S. Dockery di dalam buku The Challenge of Postmodernism an Evangelical Engagement menuliskan tentang pengaruh dari postmodernisme:

Postmodernism is a new set of asusumption about reality, which goes far beyond mere relativism. It impact our literature, our dress, our art, our

${ }^{26}$ Sugiharto, Postmodernisme : Tantangan Bagi Filsafat, 24.

27 Stevri I. Lumintang, Keunikan Theologia Kristen Di Tengah Kepalsuan (Batu: Departemen MultiMedia YPPII, 2010), 312.

28 Ariel Heryanto, "Postmodernisme dan Kelas Menengah Indonesia," Surabaya Post, 16 Desember 1993, 6. 
architectur, our music, our sense right or wrong, our self identity and our theology. ${ }^{29}$

Dengan demikian pemikiran postmodernisme mempengaruhi berbagai bidang baik itu literatur, seni dan kebenaran. Literatur dan seni sejarah yang ditolak membentuk pemikiran postmodernisme yang akhirnya anti terhadap sejarah.

\section{Pluralisme Perspektif}

Pluralisme perspektif artinya cara pandang yang memahami sebuah fenomena secara beragam. Prinsip subyektifisme membuat postmodernisme menghadirkan cara pandang yang plural. $^{30}$ Berkenaan dengan hal itu dalam konteks teologi dan kehidupan gereja postmodernisme juga mempengaruhi. Dengan demikian postmodernisme juga membawa pemikiran iman Kristen pada konsep baru dan mengabaikan tradisi. ${ }^{31}$

\section{Relativitas}

Salah satu ciri dari postmodern adalah mengedepankan relativisme. Hal tersebut didasarkan karena postmodernisme menekankan kebenaran subyektif

29 David S. Dockery, The Challenge of Postmodernism an Evangelical Engagement (Grand Rapids: Baker Books, 1995), 14., Bdg. Hok Liong menuliskan pengaruh postmodenisme dalam banyak aspek, yaitu literatur, sejarah, sains dan agama (Hok Liong, "Postmodern Era: Perspectives From An Indonesian Christian," Jurnal Stulos 9, no. 1 (2000): 14-15.) 2005), 230.

30 James W. Sire, The Universe Next Door A Basic Worlview Catalog (Surabaya: Momentum,

${ }^{31}$ Stevri I. Lumintang, Keunikan,..., 312 Bdg. Ramly B. Lumintang " Postmodernisme dengan filosofinya, "pemikiran" dan semangat ajaran yang terkandung di dalamnya, telah meruntuhkan modernisme. Di samping itu memunculkan sesuatu yang "baru" seperti penekanan pada humanism (anthroposentris) yang ekstrem (sangat berlebihan) terutama dalam kebebasannya, mengokohkan relativisme absolut (semua adalah relatif) sebagai patokan segala sesuatu, berdasarkan prespektif (paradigma seseorang) untuk menjadi ukuran dalam mencari kebenaran, gaya hidup yang bebas berekspresi (mengikuti kata hati) demi mencapai kesenangan, pola hidup : konsumeristik, sektarianistik, komersialistik, hedonistik, dan pragmatistik, yang semuanya telah merambah serta mempengaruhi hamper ke seluruh aspek kehidupan manusia (baik bidang sosial, politik, ekonomi, kebudayan, seni, filsafat, etika dan termasuk theology." (Lih. B. Lumintang, Bahaya Postmodernism Dan Peranan Kredo Reformed, 38.) 
karena itu kaum postmo menyatakan kebenaran itu adalah relatif. Kaum postmo memandang kebenaran sebagai sesuatu yang relatif termasuk pandangan iman Kristen dianggap sebagi sesuatu yang relatif. ${ }^{32}$ Pandangan tersebut menempatkan kehidupan tanpa dasar yang absolut.

\section{Tantangan Postmodernisme Terhadap Teologi}

Di abad pertengahan, teologi adalah ratu dari ilmu pengetahuan. Di zaman pencerahan, filsafat dan khususnya ilmu pengetahuan, menjadi bagian terdepan dari perubahan kultur intelektual. Di zaman postmodern, teori sastra memimpin perubahan itu. ${ }^{33}$ Postmodernisme adalah filsafat yang membentuk pemikiran manusia kepada sebuah relativisme. Pemikirian relativisme yang dibentuk oleh postmodernisme telah meruntuhkan sebuah prinsip adanya kebenaran yang absolut. $^{34}$

Dalam pemikiran teologis prinsip kebenaran absolut adalah prinsip utama dalam meyakini kebenaran Alkitab adalah firman Allah dan Yesus Kristus adalah satu-satunya Juruselamat. Pemikiran subyektifisme, relativisme, anti sejarah dan pluralisme perspektif telah meresap ke dalam pemikiran teologis. Sehingga pada masa kini muncul konsep pemikiran teologi pluralisme. Subyektifisme yang berkembang dalam postmodernisme membuat manusia menerima segala sesuatu berdasarkan apa kata dirinya. Munculnya spirit yang menentang sejarah

32 Lumintang, Keunikan Theologia Kristen Di Tengah Kepalsuan, 312.

${ }^{33}$ Sire, The Universe Next Door A Basic Worlview Catalog, 249. Pengetahuan."

${ }^{34}$ Setiawan dan Sudrajat, "Pemikiran Postmodernisme Dan Pandangannya Terhadap IImu 
membawa manusia mempertanyakan sejarah Alkitab dan meragukan konteks yang ada. ${ }^{35}$

Teologi dalam zaman postmodernisme banyak didasarkan bukan kepada obyek kebenaran, namun keberanan berdasarkan dari subyek. Dengan demikian jika seseorang mengatakan sesuatu itu salah maka tetap salah, jika benar maka tetap benar. Dengan demikian teologi yang subyektifisme akan banyak menghancurkan pemikiran teologis yang sudah diabsahkan secara umum oleh Gereja. ${ }^{36}$ Gereja terancam memiliki banyak warna baik itu dalam doktrin, praktek ibadah dan hukum-hukum gereja. Keberagaman ini didasarkan dari subyek atau pelaku dari teologi itu sendiri.

Relativisme tidak hanya menghadirkan teologi yang beragam, namun bisa mentiadakan keunikan teologi. Keseragaman dapat dilihat jika ada perbedaan, namun relativisme bisa juga menjadikan teologi kehilangan identitas unik, lalu melebur menjadi satu identitas. Akibat pusat obyektif kebenaran ditolak, maka teologi kembali pada subyektifitas, kemudian setiap subyek memiliki komunitas, dan komunitas itulah yang menjadi penentu diterima atau tidaknya kebenaran. ${ }^{37}$ Teologi demikian menghasilkan pluralisme teologi. Dalam pluralisme semua keunikan dihilangkan dan digantikan etik global. ${ }^{38}$ Sehingga dalam pembahasan tentang iman Kristen, tidak perlu menunjukkan tentang esensi dari finalitas Injil dan Personalitas Yesus Kristus. 2019), 1320

${ }_{35}$ Gerald Bray, Allah Telah Berfirman Sejarah Theologi Kristen, vol. 2 (Surabaya: Momentum,

${ }^{36}$ Ramly B. Lumintang menuliskan point-point penting dampak postmodernisme bagi Gereja, yaitu: a). Pesimistik orang postmodernisme terhadap Gereja (Gereja menjadi tawar). b). Gereja menjadi budak atau pelayan penyedia kebutuhan psikologis jemaat (Gereja menjadi "Rumah sakit jiwa" bagi orang postmodernisme). c). Gereja menjadi lab kepemimpinan dan aktualisasi diri jemaat. (Lih.: B. Lumintang, Bahaya Postmodernism Dan Peranan Kredo Reformed, 174-179.)

${ }^{37}$ B. Lumintang, 157.

38 H.W.B. Sumakul, Postmodernitas: Memaknai Masyarakat Plural Abad Ke - 21 (Jakarta: BPK Gunung Mulia, 2012), 120. 
Teologi ditantang untuk memberikan jawaban bagaimana mempertahankan diri dari reduksi pemikiran filosofis postmodernisme terhadap finalitas Alkitab dan Yesus Kristus. Prinsip postmodernisme yang selalu berbicara memaknai kembali sebuah makna yang telah ada menjadi spirit untuk mempertanyakan kembali apa yang telah menjadi pengajaran fundamental dalam iman Kristen. ${ }^{39}$ Tantangan inilah yang mesti dijawab oleh para teolog Kristen. Apalagi banyak perkembangan teknologi dan arkeologi yang sering dipakai untuk menjadi data memaknai kembali keabsahan Alkitab.

Teologi Kristen mendapatkan tantangan dalam mempertahankan presuposisi iman Kristen. Dengan demikian Christian worldview juga sedang diserang dan digantikan oleh prinsip postmodernisme dengan filsafatnya. Presuposisi Kristen tentang finalitas Alkitab dan Personalitas Allah Tritunggal sedang digeserkan oleh para pemikir postmodernisme, yang pada intinya meragukan Alkitab dan mereduksi Allah Tritunggal. ${ }^{40}$

Dalam konteks missiologis, postmodernisme juga memberikan pengaruh yang besar, hilangnya prinsip misi yang Theosentris berganti dengan pemikiran misi yang anthroposentris. ${ }^{41}$ Misi yang dimulai dari Allah, kepada Gereja dan ditujukan kepada dunia berganti menjadi misi Allah kepada dunia langsung. ${ }^{42} \mathrm{Hal}$ demikian mereduksi panggilan misi gereja bahkan mentiadakan gereja untuk

39 B. Lumintang, Bahaya Postmodernism Dan Peranan Kredo Reformed, 169-171.

40 B. Lumintang, 183-185.

${ }^{41}$ Muriwali Yanto Matalu, Apologetika Kristen (Malang: GKKR, 2018), 150.

55.

42 Stevri I. Lumintang, Missiologia Kontemporer (Batu: Departemen Multi-Media YPPII, 2009), $51-$ 
memikul penuh tanggung jawab misi. ${ }^{43}$ Dunia yang berdosa dipercaya dapat melakukan misi dan menerangi kegelapan dunia.

Dalam aspek eskatologis postmodernisme juga memberikan pengaruh yang sangat besar. Prinsip sejarah penebusan yang berpusat dan disempurnakan oleh Yesus beralih kepada penebusan sejarah. Sehingga karya Yesus dipandang belum final dalam melakukan penebusan karena penebusan masih dilakukan dalam tiap sejarah manusia. Sejarah yang dipercaya akan bemuara kepada Allah justru digantikan dengan sejarah yang bermuara kepada manusia. ${ }^{44}$ Manusia menjadi penentu eskatologis bukan Allah yang menentukan.

\section{Tinjauan Teologis Terhadap Postmodernisme}

Agar dapat membentuk pemahaman teologis tentang postmodernisme maka akan dilakukan peninjauan secara teologis terhadap postmodernisme. Tinjauan teologis ini didasarkan pada prinsip memahami adanya realitas postmodernisme di dalam Alkitab dan bagaimanakah Allah menyikapinya.

\section{Postmodernisme adalah filsafat Anti-Kebenaran}

Dalam konteks Kejadian 3, ketika manusia akan jatuh ke dalam dosa, spirit postmodernisme sudah muncul. Hal tersebut terlihat pada waktu diskusi iblis yang memakai ular dan Hawa. Dalam komunikasi tersebut menunjukkan bagaimana Iblis memutarbalikkan kebenaran, menjadi kebenaran palsu. Lalu Hawa juga menyampaikan kebenaran tidak pada porsi yang tepat dan banyak yang ditambahkan. Gambaran tersebut menunjukkan bahwa spirit postmodernisme yang diwakili oleh relativisme telah hadir di awal kehidupan manusia dan spirit

43 Bdg. Pemikiran Grenz tentang Sifat-sifat Injil Postmodern, yaitu: Injil postindividualistik, Injil Postrasionalitik, Injil postdualistik dan Injil postnoetosentrik. (Lih.: Stenly J. Grenz, A Primer On Postmodenism, trans. oleh Wilson Suwanto (Yogyakarta: ANDI, 2001), 271-281.)

44 Nelman A. Weny, "Allah Postmodern (Pendekatan Onto - Eskatologi Richard Keany)," Jurnal Waskita: Jurnal Studi Agama dan Masyarakat, t.t., file:///C:/Users/Hp/Downloads/1304-Article\%20Text-34591-10-20171025.pdf. 
ini adalah buah dari keinginan manusia yang dapat jatuh ke dalam dosa dan konsep dari iblis.

Dalam perkembangan sejarah kehidupan manusia prinsip relativisme juga diperlihatkan dalam peristiwa Firaun yang mengeraskan hati, umat Israel yang menolak Teokrasi, para raja-raja yang melakukan kejahatan dan sikap jemaat Galatia yang menerima Injil Palsu yang sesungguhnya bukan Injil dan Yohanes saudara Tuhan Yesus juga menuliskan bahwa adanya spirit anti-Kristus.

Berbagai peristiwa yang terjadi terkait dengan prinsip anti-Kebenaran, Allah juga memberikan respon terhadap ekspresi manusia yang melakukannya, hal tersebut dapat kita temukan melalui Alkitab Allah memberikan hukuman kepada Iblis dan manusia di Taman Eden, Allah juga menyatakan kuasa-Nya melalui tulah dan terbelah-Nya laut teberau di depan Firaun. Allah membiarkan umat Israel diserang bangsa-bangsa di sekitar Kanaan, Allah membuang umat Israel ke Asyur dan ke Babel. Namun dalam PB Allah memakai rasul Paulus untuk menegur jemaat Galatia dan memberi kesempatan kepada mereka untuk kembali kepada kebenaran dan Allah juga memakai Yohanes untuk melakukan antisipasi terhadap ancaman spirit anti-Kristus. ${ }^{45}$

Dalam teologi Reform menyatakan bahwa segala kebenaran adalah kebenaran Allah. Kebenaran yang benar yang dilakukan manusia karena manusia merefleksikan Sang Pencipta yang adalah kebenaran. ${ }^{46}$ Namun kebenaran tanpa Iman kepada Yesus Kristus maka kebenaran itu hanyalah bersifat umum. Dalam anugerah umum manusia dapat melakukan kebaikkan dan kebenaran yang relatif

45 Matalu, Apologetika Kristen, 104.

${ }^{46}$ Arthur F. Holmes, Segala Kebenaran Adalah Kebenaran Allah (Surabaya: Momentum, 2009), 20. 
namun keultimatan dalam melakukan kebenaran hanya ketika Allah Tritunggal memberikan kebenaran kepada manusia.

Dengan demikian postmodernisme adalah spirit yang menolak kebenaran mutlak, dan mencari pengganti kebenaran yang telah absolut. ${ }^{47}$ Pemikiran demikian adalah benih pemikiran dari Iblis bapa segala pendusta dan hal ini berpotensi dapat muncul dalam keinginan manusia yang dapat jatuh ke dalam dosa. Allah dalam pemeliharaan-Nya melakukan banyak cara untuk membawa manusia kepada prinsip kebenaran sejati, sekalipun manusia mulai bergeser kepada postmodernisme, namun Allah tetap memberikan banyak teolog untuk membongkar kepalsuan postmodernisme dan Allah juga masih memberikan kesempatan kepada mansia yang pernah mengikuti prinsip postmodernisme untuk kembali kepada prinsip absolutsitas Kebenaran Alkitab.

\section{Allah adalah Allah yang Absolut Dalam Hakikat Kebenaran-Nya}

Di dalam Alkitab menyatakan bahwa kebenaran Allah adalah kebenaran yang tidak akan berubah sampai selamanya. Ketidakberubahan tersebut didasarkan pada pribadi dan karya Allah yang tidak berubah (Ayb. 23: 13; Maz. 46: 2-4; Mal. 3: 6; Ro. 3: 3; 8: 29-30). Ketidakberubahan Allah menunjukkan keabsolutan-Nya. Dalam Keluaran 3: 14 Allah menyatakan "I'AM THAT I'AM." Hal tersebut menunjukkan ketidakbergantungan pada yang lain. ${ }^{48}$ Dengan demikian Allah adalah absolut pada diri-Nya sendiri.

Dengan mempertahankan keabsolutan Allah maka manusia dapat memiliki satu keyakinan bahwa ada kebebenaran absolut dalam dunia ini. Tetapi jika manusia tidak mempercayai keabsolutan Allah maka, manusia harus memberikan

${ }^{47}$ Lumintang, Keunikan Theologia Kristen Di Tengah Kepalsuan, 312-313.

48 Herman Bavinck, Dogmatika Reformed, ed. oleh John Bolt, trans. oleh John Vriend, Ichwei G. Indra, dan Irwan Tjulianto, vol. 2, Allah dan Penciptaan (Surabaya: Momentum, 2012), 113-114. 
banyak bukti untuk mempertahankan argumentasi relativismenya. Keabsolutan Allah sudah terlihat dari penciptaan, pada mulanya sebelum ada firman Allah telah ada dengan demikian, jika dilakukan pengkajian secara logis untuk menemukan causa prima dari sesuatu yang membentuk alam semesta, maka tidak akan ada habisnya, jika tidak bertumpu kepada yang Ilahi, yaitu Allah Tritunggal.

Dalam teologi Reform sangat menjujung tinggi kedaulatan Allah. Kedaulatan Allah menjadi dasar utama beroperasinya sifat-sifat Allah Tritunggal yang lain. Kebenaran, keadilan dan kasih tidak akan beroperasi jika Allah Tritunggal tidak berdaulat sepenuhnya. Oleh karena itu kedaulatan Allah Tritunggal menunjukkan bahwa apa yang dilakukan Allah Tritunggal memiliki keabsolutan. Karena tidak mungkin ada kontradiksi, jika berdaulat mana mungkin tidak absolut, dan jika absolut pastilah berdaulat.

Keabsolutan Allah Tritunggal juga menunjukkan keragaman yang absolut. Keragaman yang absolut di dalam Diri Allah Tritunggal direfleksikan di dalam kehidupan manusia. Sehingga perbedaan bisa ditemukan karena adanya keragaman, tetapi jika tidak ada keragaman maka semua menjadi nihil. ${ }^{49}$ Hal ini bertentangan dengan postmodernisme yang melahirkan banyak keragaman namun merusak keabsolutan. Allah Tritunggal adalah absolut dalam kasih dan keadilanNya karena dalam keabsolutan tersebut ada keragaman, sehingga nilai kasih dan keadilan menjadi absolut dari mulanya. Pemikiran logis demikian akan menghancurkan pemikiran postmodernisme yang tidak mengakui adanya keabsolutan kebenaran.

49 Will Slocombe, Nihilism and The Sublime Postmodern (New York: Routledge, 2006), 139. 


\section{Manusia tidak memiliki kebenaran pada dirinya sendiri}

Kebenaran manusia didasarkan pada kebenaran Allah Tritunggal. Ulangan

9: 5 menunjukkan bahwa tidak ada kebenaran dalam diri umat Israel, mereka dibenarkan karena kebenaran Allah Tritunggal. Hal tersebut menunjukkan manusia tidak memiliki kemandirian dalam kebenaran. 10 hukum Alllah Tritunggal yang diberikan di Gunung Sinai menunjukkan bahwa manusia tidak mampu membuat standar kebenaran, karena di dalam diri manusia tidak ada kebenaran pada dirinya sendiri.

Dalam hukum moralitas, manusia harus menerima bahwa ada pembuat hukum moral. Lalu pembuat hukum moral haruslah memiliki standar dan kualifikasi moral yang tinggi, oleh karena itu tidak mungkin manusia mampu memenuhi standar tersebut, maka akhirnya standar yang pantas untuk membuat hukum moral adalah standar yang nilainya ilahi. ${ }^{50}$ Dalam iman Kristen Allah Tritunggal adalah standar hukum moral karena Allah Tritunggal adalah pembuat Hukum Moral, dan hukum tersebut dinyatakan di dalam Alkitab firman Allah. ${ }^{51}$

Dalam Kitab Kejadian pasal 3 menunjukkan fakta bahwa ketika manusia ingin menjadikan dirinya standar kebenaran dan moral justru manusia mendapati dirinya tidak memiliki dan mampu menjadikan dirinya standar kebenaran. Ketika manusia menjadikan dirinya standar moral manusia justru membongkar kelemahannya sebagai manusia yang hanya ciptaan. Dalam teologi Reform menyatakan dengan tegas kerusakan total manusia (total depravity of man). ${ }^{52}$ Kerusakan total manusia yang disebabkan oleh dosa membuat mansuia tidak

50 Norman L. Geisler dan Paul D. Feinberg, Filsafat dari Perspektif Kristiani (Malang: Gandum Mas, 2013), 320-325.

51 W. Andrew Hoffecker dan Gary Scott Smith, Membangun Wawasan Dunia Kristen, vol. 1 (Surabaya: Momentum, 2011), 250.

52 Herman Bavinck, Dogmatika Reformed, vol. 3 (Surabaya: Momentum, 2012), 140. 
memiliki kualifikasi untuk dijadikan sebagai standar kebenaran. Jika manusia memaksakan dirinya menjadi standar kebenaran maka manusia akan mengalami nihilisme dalam mengerti standar kebenaran. ${ }^{53}$

Postmodernisme mengklaim bahwa manusia secara subyektif dapat dijadikan standar kebenaran, namun faktanya manusia tidak mampu memenuhi standar moral dalam kehidupannya. Sekalipun ada catatan sejarah ada manusia yang hidup dengan sangat bermoral baik, namun catatan sejarah juga memberikan fakta bahwa ada kesalahan yang juga pernah dilakukan oleh manusia yang dikatakan bermoral. Dengan demikian pernyataan kelompok postmodernisme yang menjadikan manusia sebagai standar kebenaran adalah absurd. Manusia harus mengembalikan standar kebenaran kepada Allah Tritunggal.

\section{Implikasinya Bagi Iman Kristen}

Setelah memberikan penjabaran tentang prinsip pemikiran postmodernisme, tantangan yang ditimbulkan postmodernisme, dan tinjauan teologis terhadap postmodernisme bagi iman Kristen maka ada beberapa implikasi bagi iman Kristen.

\section{Menyatakan Kebenaran Final Iman Kristen}

Postmodernisme menyatakan kerelatifan terhadap kebenaran dan hal itu termasuk dalam kebenaran iman Kristen. Finalitas iman Kristen diragukan, dicampuradukan dan ditolak. Namun pandangan tersebut justru membawa kepada nihilisme kebenaran. Iman Kristen tidak timbul dari subyetifitas manusia, tetapi Iman Kristen timbul dari karya Allah Tritunggal. Allah berkarya menyatakan kebenaran final di dalam Alkitab. Alkitab menerangkan bahwa Yesus Kristus 2019), 73.

53 Gerald Bray, Allah Telah Berfirman Sejarah Theologi Kristen, vol. 1 (Surabaya: Momentum, 
adalah puncak dari penyataan Allah yang final. Oleh karena Iman Kristen telah berhasil mereduksi klaim kebenaran dari postmodernisme, maka sudah sepatutnya Iman Kristen kembali diwartakan sebagai satu-satunya kebenaran. Maka pelaksanaan great commison kembali dilakukan, maka hanya dengan menyatakan kebenaran Injil maka dunia akan memahami kebenaran sejati.

\section{Iman Kristen Memiliki Keunikan Yang Tidak Bisa Dirubah}

Postmodernisme menyatakan keunikan setiap agama ditiadakan, termasuk keunikan dari iman Kristen. Teologi Reform telah mereduksi klaim postmodernisme yang ingin mengaburkan keunikan bahkan sampai mentiadakan. Alkitab Firman Allah dan Yesus Kristus satu-satunya jalan, kebenaran dan keselamatan adalah point utama dalam keunikan Iman Kristen. Karena postmodernisme hanya menghasilkan kenihilan maka keunikan Iman Kristen tetap dipertahankan. Keunikan Iman Kristen tidak berubah karena Allah Tritunggal adalah Allah yang konsisten, koheren dan komprehensif.

\section{Iman Kristen Satu-satunya Alat Uji Membongkar Kepalsuan Postmodernisme}

Iman Kristen berhasil lolos terhadap kritikan postmodernisme, justru pada saat ini filsafat postmodernisme telah runtuh oleh ujian kebenaran dari iman Kristen. Maka sudah sepatutnya menjadikan iman Kristen sebagai satu-satunya alat uji untuk postmodernisme. Iman Kristen telah terbuka diuji oleh postmodernisme yang justru malah membongkarbalik kepalsuan postmodernisme.

\section{KESIMPULAN}

Postmodernisme adalah peralihan dari modernisme, namun peralihan ini lebih cenderung kepada prinsip atau filosofi daripada bentuk. Peralihan ini dilatarbelakangi oleh kegagalan filsafat modern menjawab tantangan kemanusiaan 
pada zamanya. Postmodern juga tidak meninggalkan berbagai hasil dari zaman modern, tetapi postmodern memberikan pandangan baru dalam menggunakan hasil-hasil modernisme. Postmodernisme dengan spirit relativisme memberikan kesan mengancam iman Kristen. Dan situasi yang terhindarkan iman Kristen terbuka dengan setiap ujian-ujian filosofis dari postmodernisme. Namun setelah beberapa waktu ujian tersebut justru menunjukkan ketahanan iman Kristen terhadap berbagai macam kritik. Sekarang justru postmodernisme berhasil dibongkar kepalsuannya oleh iman Kristen. Teologi Reform memiliki kapasitas yang sangat cukup untuk membongkar kepalsuan dari postmodernisme. Dan pada akhirnya finalitas iman Kristen dan keunikan dalam iman Kristen, tetap bertahan dan tetap diwartakan bagi dunia ini. Iman Kristen tetap berpegang pada kebenaran absolut yang didasarkan pada Allah Tritunggal, Alkitab firman Allah dan Yesus Kristus satu-satunya jalan keselamatan.

\section{DAFTAR PUSTAKA}

B. Lumintang, Ramly. Bahaya Postmodernism Dan Peranan Kredo Reformed. Batu: PPII, 2010.

Bavinck, Herman. Dogmatika Reformed. Disunting oleh John Bolt. Diterjemahkan oleh John Vriend, Ichwei G. Indra, dan Irwan Tjulianto. Vol. 2. Allah dan Penciptaan. Surabaya: Momentum, 2012.

_. Dogmatika Reformed. Vol. 3. Surabaya: Momentum, 2012.

Bray, Gerald. Allah Telah Berfirman Sejarah Theologi Kristen. Vol. 2. Surabaya: Momentum, 2019.

Allah Telah Berfirman Sejarah Theologi Kristen. Vol. 1. Surabaya: Momentum, 2019.

Bustan, Abdy. "Postmodernisme." Www.kompasiana.com. Kompasiana, 24 Juni 2014. https://www.kompasiana. com/abdibusthan/5975d1c02bbb132bfd12c022/postmodernisme?page=all . 
Dockery, David S. The Challenge of Postmodernism an Evangelical Engagement. Grand Rapids: Baker Books, 1995.

Gaut, Willy. Filsafat Postmodernisme: Jean Francois Lyotard. Maumere: Penerbit Ledalero, 2010.

Geisler, Norman L., dan Paul D. Feinberg. Filsafat dari Perspektif Kristiani. Malang: Gandum Mas, 2013.

Grenz, Stenly J. A Primer On Postmodenism. Diterjemahkan oleh Wilson Suwanto. Yogyakarta: ANDI, 2001.

Groothuis, Douglas. Pudarnya Kebenaran. Surabaya: Momentum, 2010.

Heryanto, Ariel. "Postmodernisme dan Kelas Menengah Indonesia." Surabaya Post. 16 Desember 1993.

—_. "Postmo-Phobia." Jawa Pos, 17 April 1994.

Hoffecker, W. Andrew, dan Gary Scott Smith. Membangun Wawasan Dunia Kristen. Vol. 1. Surabaya: Momentum, 2011.

Holmes, Arthur F. Segala Kebenaran Adalah Kebenaran Allah. Surabaya: Momentum, 2009.

Huyssteen, Wetzel van. Theology and Justification of Faith: Constructing Theories in Systematic Theology. Grand Rapids: William B Eerdmans Publishing Company, 1989.

Kon, D.A. Lyon. "Modernity And Postmodernity." Dalam New Dictionary of Christian Ethics \& Pastoral Theology, disunting oleh David J. Atkinson, David F. Field, Arthur F. Holmes, dan Oliver O’Donovan, 597. Illionis: IVP Academic, 1995.

Lie, Hali Daniel. "Abad Pertengahan, Modernisme \& Postmodernisme." Jurnal Teologi Stulos 8 (2009): 1. https:/ /www.academia.edu/ 38587556/Abad_ Pertengahan_Modernisme_and_Postmodernisme.

Liong, Hok. "Postmodern Era: Perspectives From An Indonesian Christian." Jurnal Stulos 9, no. 1 (2000): 14-15.

Lubis, Akhyar Yusuf. Postmodernisme: Teori dan Metode. Jakarta: Rajawali Press, 2014.

Lumintang, Stevri I. Introduksi Theologia Sistematika. Jakarta: IThI, 2019.

- Keunikan Theologia Kristen Di Tengah Kepalsuan. Batu: Departemen Multi-Media YPPII, 2010.

_. Missiologia Kontemporer. Batu: Departemen Multi-Media YPPII, 2009. 
Matalu, Muriwali Yanto. Apologetika Kristen. Malang: GKKR, 2018.

Megill, Allan. Prophets of Extremity: Nietzsche, Heidegger, Foucault, Derrida. Berkeley and Los Angeles: University of California Press, 1985.

Moeliono, Anton M. Kamus Besar Bahasa Indonesia. Jakarta: Balai Pustaka, 1990.

N, N. "Middle Ages." En.wikipedia.org. Wikipedia. Diakses 10 Agustus 2019. http://en.wikipedia.org/wiki/Middle_Ages.

"Modernisme." En.wikipedia.org. Wikipedia. Diakses 10 Agustus 2019. https: //en.wikipedia.org /wiki/Modernisme.

O’Donnell, Kevin. Postmodernisme. Yogyakarta: Kanisius, 2009.

Prent, K. Kamus Latin-Indonesia. Yogyakarta: Kanisius, 1969.

Probo, Bayu. "Teologi Postmodern Ditolak Atau Diterima?" Satu Harapan, 25 September 2014. http://www.satuharapan.com/read-detail/read/teologipostmodern-ditolak-atau-diterima.

Setiawan, Johan, dan Ajat Sudrajat. "Pemikiran Postmodernisme Dan Pandangannya Terhadap Ilmu Pengetahuan." Jurnal Filsafat 28, no. 1 (28 Februari 2018): 25. https://doi.org/10.22146/jf.33296.

Sire, James W. The Universe Next Door A Basic Worlview Catalog. Surabaya: Momentum, 2005.

Slocombe, Will. Nihilism and The Sublime Postmodern. New York: Routledge, 2006.

Soendari, Tjutju. "Metode Penelitian Deskriptif." File.upi.edu. UPI. Diakses 15 Agustus 2020. http: //file.upi.edu /Direktori/FIP/JUR. _PEND._LUAR_BIASA/ 195602141980032TJUTJU_ SOENDARI/ Power_Point_Perkuliahan/ Metode_PPKKh/Penelitian__Deskriptif.ppt_[Compatibility_Mode].pdf.

Sugiharto, I. Bambang. Postmodernisme: Tantangan Bagi Filsafat. Yogyakarta: Kanisius, 1996.

Sumakul, H.W.B. Postmodernitas: Memaknai Masyarakat Plural Abad Ke -21. Jakarta: BPK Gunung Mulia, 2012.

Weny, Nelman A. "Allah Postmodern (Pendekatan Onto - Eskatologi Richard Keany)." Jurnal Waskita: Jurnal Studi Agama dan Masyarakat, t.t. file:///C:/Users/Hp/Downloads/1304-Article\%20Text-3459-1-1020171025.pdf. 